\title{
сОЦІОЛОГІя
}

УДК 101.316.77

DOI https://doi.org/10.32837/apfs.v0i32.1042

\author{
А.О.Олейник \\ ORCID ID: https://orcid.org/0000-0002-7102-9092 \\ аспірант кафедри філософії та політологї \\ Національної металургійної академї України
}

\section{НОВА ЛЮДИНА В ЕРІ ТЕХНОЛОГІЙ}

Постановка проблеми. Сучасні способи передачі інформації, соціальні платформи для спілкування, електронні ресурси, у яких зосереджені дані майже про кожну людину - все це результат стрімкого розвитку людини та світу навколо неї. Але чи можливий такий прогрес без регресу в інших галузях життя? Можливо, людство про це навіть не здогадується, приймаючи технологічний розвиток як належне. Зміни очікують цивілізацію щодня, варто лише новому відкриттю сколихнути світ, адже зараз набагато простіше дізнатися про це, ніж трохи більше двадцяти років тому. Інформаційні потоки мандрують навколо земної кулі й у ту саму хвилину опиняються у розпорядженні мас-медіа, а вже потім людина має до них доступ. Це дослідження актуальне саме у сьогоднішніх реаліях, коли технології запроваджують і диктують людині умови до існування, нав'язують інформацію, яку вона має використовувати для власного світогляду, і просто можливість до комфортного життя, неможливого без сучасних технологій. Інакше у людини просто не залишається вибору, вона стає «сучасним Робінзоном Крузо», але це дуже рідке явище у сучасному світі, де досі йде розділення на цивілізованих людей та аборигенів [1].

Метою дослідження є виявлення проблематики інформаційних технологій на основі праць Маршалла Маклуена. Авторами були поставлені завдання провести емпіричний експеримент із метою виявлення перспектив розвитку людини та дослідження поняття «глобальне село» [1], його актуальності у сучасному житті та майбутньому.

Аналіз останніх досліджень i публікацій. Вивченням цієї проблеми займалися такі вчені, як Маршалл Маклуен, Джеймс Мур, Огюст Конт, Ганс Йонас, Томас Кун, Імре Локатос, Ніл Постман, Фрідріх Кетлер, Жак Барзун, Анет Майер, Стівен Шейпін, Стівен Тулмін, Парсонс Толкот, Наталя Габор, Олексій Халапсіс [1-6].

Виклад основного матеріалу. Філософські роздуми щодо технологій розпочались у той момент, як з'явилася філософія. Ще філософи Древньої Греції спостерігаючи за світом i, розмірковуючи над питанням технологій, висловлювали із приводу цього власні думки. Так, наприклад, Платон [7] писав, що технологія повторює і наслідує природу. Демокрит [8] вважав, що ткацтво повторюе технологію плетіння павутини у павуків, а будівництво будинків наслідує технологію ластівок, які будують гнізда. Аристотель [9] стверджував, що технологія не тільки імітуе та наслідуе природу, а й подеколи завершує те, що не змогла завершити природа. Розпочинаючи дослідження, слід сказати, що у його основу була взята робота Маршала Маклюєна «Галактика Гутенберга» [1], у якій філософ припускає, що початок розвитку технологій почався із винаходу писемності. Порівнюючи древніх греків і китайців, він, здається, навіть дивується на певну мить, що останні не були тими, хто винайшов писемність, хоча саме вони дарували світові папір, порох, компас та ін. Цікаво, що саме китайці були першими з тих, хто винайшов друкарський верстат у IX столітті (за іншими даними, поява друкарського верстату датується VI століттям). Саме можливість записувати знання стало відривною точкою, і саме з цього моменту людина відійшла від слухового сприйняття світу до його сприйняття за допомогою зору. Він порівнюе їх як дві протилежності, наголошуючи на тому, що людина цивілізована орієнтується повністю на зоровий аспект сприйняття, тоді як племінна людина живе у світі за допомогою вуха. Маклюєн пише, що зір не дає змогу відчувати магію світу, його емоційну та пристрасну забарвленість. Це робить людину сучасності байдужою та «холодною». Маклуен цитує багатьох дослідників у різних сферах, таким чином, більш детальніше розглядає питання розвитку технології $[10 ; 11]$.

За Імре Локатосом [3], наукова революція складається з того, що одна дослідницька діяльність витісняє іншу. Він розглядає революцію з позиції нових знань, а не обернення у нову віру. Та чи насправді існує цей баланс, запропонований Локатосом? Бертран Расел, якого цитує Маклуен [1], вважає, що тоді, як суспільство засвоює новий спосіб сприйняття, переходячи від слухового 
до зорового, перебудовуючи попередні зв'язки між відчуттями у сферах праці та спілкування, у момент «засвоювання» і відбувається справжня революція, яка започаткувалася завдяки новій технології. Перехід від одного відчуття до іншого розпочався саме з Заходу, тоді як Азія, а саме Китай, зробивши крок уперед у своїх інноваційних розробках, набагато ближча до слухового сприйняття, ніж до зорового. Автор припускає, що це відбулося завдяки фонетичним особливостям китайської мови. Вона, по-перше, дуже мало зазнала змін порівняно із Західним світом [1]. По-друге, Китай у своїй історії залишався майже незмінним як територіально, так і традиційно. Це одна 3 небагатьох країн сучасності, традиції та культура якої перенесла найменше змін і зберегла свій спадок. По-трете, важливу роль грає морфологія китайської мови, побудованої на інтонаціях і наголосах. Саме тому небагатьом ученим і тим, хто вивчає китайську мову, дається мистецтво писати, складати власні твори. Писемні витвори виконані у класичному стилі традиційною китайською мовою, що за своєю структурою побудова з морфем і стилістико-синтаксичних обертів, які не зрозумілі фахівцю без досвіду і певного багажу знань. Автор припускає, що суспільство Китаю завдяки своїм особливостям сприйняття відчуває технічну революцію зовсім по-іншому, ніж це відбувається з людиною Заходу.

Західна людина, переживаючи зміни на фоні технологічного прогресу або впливу технології, змінює свій соціальний світ, виносячи домінуюче сприйняття, і тоді у культурі формується нові співвідношення почуттів і способів мислення, що впливають на такі важливі фактори: зміну цінностей у житті людини, пріоритетність, світогляд. Варто звернути увагу на те, як описує розвиток технологій Джеймс Мур [2]. Він порівнює його 3 тим, як росте людина, та виділяє три етапи: етап введення, етап проникнення й етап влади над людиною. Мур пише, що зараз людство знаходиться на етапі проникнення. Звідси можна припустити, що технології повністю не заволоділи людиною, i на це знадобиться деякий час, але не відомо, мине десять років або десять століть, перш ніж це відбудеться. Мур також пише, що розвиток технологій має бути збалансований новою етикою, яка ще не встановилася у сучасному житті. У нашому дослідженні розглянемо поняття «глобального села», яке вперше ввів Маршалл Маклуен. Це поняття характеризує суспільство, що спілкується завдяки електронних способів комунікації. На його думку, всесвітня глобалізація - це новітній феномен, котрий виник із моменту розвитку електричних технологій: радіо, телебачення, телефон, а у XXI столітті - інтернет. Ще на момент виходу книги «Галактика Гутенберга» у 1962 році, коли інтернет не існував у тому вигляді, як у сучаснос- ті, Маклуен писав, що світ стиснувся і став схожим на одне велике село, де завдяки комунікаціям людина може передавати інформацію з одного кінця землі в інший. Але якщо на той час, коли Маклуен писав свою книгу, світ, за його сприйняттям, був схожий на велике село, чи можливо таке, що зараз він розміром, наче одна кімната? Припустимо, спираючись на ситуацію у світі [1].

Інформаційні технології та засоби комунікації зараз доступні кожній людині, котра має у своїй руці смартфон і підключення до інтернету. Більш того, людина, не зареєстрована у соціальних мережах або не має навіть власної електронної пошти, зараз майже зникаючий вид [4]. Людина може комунікувати з іншою, будучи будь-де та будь-коли, але тепер можна не тільки чути голос по телефону, але й бачити зображення у режимі «онлайн», зберігаючи ефект присутності у реальному часі. Більш того, нині до розмови двох людей із різних точок землі можуть підключатися сотні, навіть тисячі людей одночасно з різних куточків світу. Як вважав Маклуен, спочатку електронні комунікації допомагали стерти грані не тільки географічні, а й культурні, соціальні й економічні. Зараз це призвело до зближення культур, рас, національностей, орієнтацій та ін. Це призвело до того, що людина дуже швидко почала засвоювати новий спосіб спілкування 3 різними суспільствами. Сучасні інформаційні технології представляють все нові способи будувати міжнародні відносини. Також Маклуен наголошує на тому, такі новітні способи спілкування перебудовують людину та їі поведінку навіть у повсякденному житті. Так, автор пише, що у своï щоденних вчинках і переживаннях всі стають схожими на людей примітивної культури, і відбувається це не через думки, до яких у людини критичне ставлення, а через чуттєвість, котра формує матрицю мислення та поведінки. Доречно розкрити термін «матриця» 3 погляду Олексія Халапсіса, де матриця - це фундаментальний набір організації принципів буття, тобто світогляд [4].

Тож, коли технологія змінює схему зв'язку почуттів і одне домінує над іншим, змінюється світогляд людини. За світоглядом людини також змінюється і соціум, у якому вона живе. У такому соціумі, де панує технологія й електронні комунікації, зникає індивід. Людина більше не може жити лише своїми відчуттями, думками, вона має швидко поглинати інформацію, фільтрувати їі та пристосовуватися до інших людей і світу загалом [1]. Звернемо увагу на соціальні мережі у всесвітній павутині інтернету. У часи Маклуена про це навіть не думали, хоча на момент виходу «Галактики Гутенберга» у 1962 році була випущена наукова робота «Galactic Network» написана Джозефом Ліклайдером [6], котрий створив детальну концепцію комп'ютерної мережі. Саме на їі базі було розроблено інтернет у тому вигляді, як зараз. 
Можна провести аналогію між тим, що говорив Маклуен про медіа, телебачення, та із соціальними мережами, де транслюється основний потік інформації. Ця інформація об'єднує людей, вони мають можливість спілкуватися й обговорювати усе, що відбувається у світі, виражаючи свою думку. Таким чином, люди формують більшість своix поглядів на політичну, соціальну, економічну складову частину життя.

Зараз можна сказати, що комп'ютер або смартфон, як і телевізор, замінив людині «племінне вогнище» [1]. Це висловлювання Маклуена порівнює сучасну людину та людину племінну, котрі мають місце щоденного загального збору для проводження свого часу. Довгий час це вогнище було відсутнє. Людей, які відійшли від племінного життя, майже нічого не об'єднувало, не буду інформаційної свободи, засобів передачі інформації та можливості швидко спілкуватися з людиною на дальній відстані. Коли розвинулися нові технології та прийшла наукова революція, що стрімко розвинули способи спілкування і засоби передачі інформації, ситуація змінилася. 3'явився зв'язок між людьми завдяки телефону та телеграфу, потім радіо та телефон, зараз - телевізор та інтернет [1]. Тобто тепер сучасна людина проводить своє дозвілля саме так, як і людина племені. Вогнище об'єднувало племінних людей, зараз це роблять телевізор і комп'ютер, охоплюючи майже весь світ, приносячи нову інформацію людям. Людина сидить біля яскраво палаючого екрану, як і декілька тисячоліть тому перед вогнем, і сотні мільйонів людей також у цей час проводять години свого життя перед телевізором або комп'ютером. Можна сказати, що глобальне село зменшилося навіть до розмірів одного племені. Аналізуючи роботу Маклуена, важко зрозуміти його враження від майбутнього. 3 одного боку, він навіть радий, що людство не стоїть на місці, продовжує розвиватися, що культура сприйняття змінюється. Між людьми з'явився інтернаціональний зв' язок, можливостей стало більше завдяки тому, що інформація стала доступніша. 3 іншого - він розуміс, що така доступність відтепер змушує людину щоразу спиратися на чуже сприйняття та розуміння, вона залишається без власної думки. На погляд Маклуена, мас-медіа нав'язують людині те, про що вона повинна думати та дотримуватися. Людина дедалі менше стає здатна осмислювати потік інформації із власного погляду, не спираючись на думку інших людей. Тож виникає суперечність між тим, що говорять, і тим, про що варто думати. Маклуен намагався донести розуміння того, що технічна революція - це насамперед революція у світогляді людини, так, знаходячи та відкриваючи щось нове, людина втрачає те, що було закладено у ній предками. Це може бути частина культурної спадщини, соціальної або моральної [1].
Ізраїльский вчений Юваль Ной Харарі [12] вважає, що скоро на новий рівень вийдуть техногуманізм і датаїзм (англ. data-ism). Вчений вважає, що це дві нові релігії, які зараз поширюються у всьому світі, охоплюючи дедалі більше людей. Харарі був не першим, хто ввів термін «датаїзму», але він його розширив, назвавши новою ідеологією, у якій Всесвіт складається з інформаційних потоків, а об'єкт може мати цінність, лише якщо бере участь у обробці та генерації нових даних, інформації. Інформація, навіть приватна, має бути загальнодоступною, а це має негативний вплив і сприймається як неприйнятна умова. Харарі пише, що людина втратила власну цінність, передавши всю владу технологіям, вважаючи їх навіть за нових богів, яких невдовзі стануть називати надлюдьми, адже вони навіть зможуть досягти безсмертя. Про це писав Олексій Халапсіс [5], розмірковуючи над майбутнім, де у світі людей панують біороботи. Вони матимуть власні права, приватне життя, ділитимуть із людьми робочі місця, для них будуть писати юридичні закони та закони моралі. Вже зараз технології домінують над людиною, маючи доступ до більшої кількості інформації. Вони вибудовують алгоритми та зв'язки, завдяки яким життя здається легшим, а насправді йде постійний збір інформації. Коли потік інформації зникне, людина перестане бути частиною системи та бути цінною, що суперечить основній сучасній філософії - гуманізму [13]. Тобто сьогодні технології й інформаційний прогрес стають невід'ємною частиною життя. Більше того, якщо водночас зникнуть ці технології, можливо, навіть зникне звичне життя, і людина буде обмежена у всіх його сферах. Передача інформації стане неможливою, якщо позбавити людину джерела світла, адже без електростанцій, які подають живлення, стане неможливим навіть купити продукти у супермаркеті, або зняти готівку, водночас буде втрачено зв'язок із близькими та, можливо, з усім світом. Лікарні втратять можливість зберігати та дарувати життя людині, адже багато чого залежить саме від апаратів. Якщо в одному місті повністю зникне світло, за більш ніж 24 години може початися анархія, тому що зараз люди залежні саме від електрики.

Лише за 200 років людина стала залежна від природного явища, котре змогли застосовувати на користь людства, а менш ніж за 50 років з'явилася цілий Всесвіт (тобто «система», яку уявляють як новий Всесвіт у ідеології датаїзму), що створює маленькі світи та дарує нові життя, вираховує цінність життя, знає усе і про все. Цей феномен можна називати новим Богом. Можна сказати, що «передбачення» Маклуена стосовно майбутнього людства справдилося. Маючи величезні можливості, людина має виконувати роль у створеній нею ж системі. Окремо варто сказати про те, що 
система повинна упорядковувати життя людини, створюючи нові правила, закони та норми, які сьогодні відсутні. Соціальні мережі намагаються контролювати кожен контент, котрий людина поширює для аудиторії. Кіберполіція відстежує інформацію, що може зашкодити або похитнути стан тієї чи іншої країни. Контент із жорстокістю видаляється на основі правил користування домену або вебсайту та ін. $[14 ; 15]$.

Інформаційно-технічна революція відкрила для людини багато можливостей, щоб зробити життя набагато зручнішим, але поступово людина стає більш залежною від власної зони комфорту. Можна сказати, що людина повернеться до первісного періоду існування, і замість екранів пристрої буде проводити час біля "великого вогнища». Усі зв'язки, які здобула людина за період існування електрики, будуть втрачені, а існування у звичному житті буде неможливим. Зона комфорту людини перетворюється на певні обмеження у повсякденному житті, до яких необхідно пристосовуватися, адже зміни очікують людину сьогодення та людину майбутнього.

Висновки. Перед людиною постає багато невирішених питань: по-перше, необхідно вирішити етичні проблеми, що виникли 3 появою соціальних мереж, а також проблеми моральні. По-друге, перед людиною стоять екологічні проблеми, які зараз актуальні у всьому світі, адже технологічних прогрес шкодить природі. По-трете, інформаційні технології та засоби комунікації використовуються задля політичних і економічних інтересів. У стрімкому розвитку науки людина, змінивши власну матрицю, стала особливим видом, тобто вже не homo sapiens, a homo apparatibum - людиною техніки. Цей вид розвивається та популяризується у сучасному світі з кожним новим винаходом, який має свій вплив на людину. Людина вже не може почуватися повноцінною без пристроїв, до яких вона звикла, та без електрики; нові технології стають частиною не тільки життя, тепер людина стала ланкою у потоках інформації, її поповненні та зберіганні.

Отже, саме філософська проблема інформаційних технологій залишається відкритою. У майбутньому перспектива розвитку цієї проблеми стане більшою, адже відбувається перехід сфер людського життя в онлайн-простір, що відбувається завдяки технологіям. Вирішенням може стати призупинення впровадження технологій у життя людей без попереднього формування у собі моральних та етичних принципів, підкріплених законами, нормами та правилами. Ці принципи мають бути чітко сформульовані, не суперечити культурним цінностям і звичаям, нести у собі моральний контекст, користь для людини, повинні бути дотримані основні релігійні канони. Таким чином, новітні технології та наука має мати уре- гульовані рамки, що контролюють їхній вплив на людей, розвиток, світогляд і відчуття. Це допоможе зберегти homo sapiens як у філософському контексті існування, так і фізичному сприйнятті у сьогоденні та майбутньому.

\section{Jimepamypa}

1. McLuhan M. The Gutenberg Galaxy: The making of typographic man. Toronto : University of Toronto Press, 1962. $294 \mathrm{p}$.

2. Moor J.H. Why we need better ethics for emerging technologies. Ethics and Information Technology. № 7. 2005. P. 111-119.

3. Lakatos I. The methodology of scientific research programmes. Cambridge : Cambridge University Press, $1980.250 \mathrm{p}$.

4. Халапсис А.В. Зеркало Клио. Днепр : Середняк Т.К., 2017.

5. Halapsis A.V. Gods of transgumanism. Anthropological Measurements of Philosophical Research. № 16. 2019. P. 78-90.

6. Licklider J.C. Man-computer symbiosis. Transactions on Human Factors in Electronics. № HFE-1. 1960. P. 4-11.

7. Платон. Полное собрание сочинений в одном томе. Москва : Альфа-книга, 2016. 1311 с.

8. Diels H. Die Fragmente der Vorsokratiker. Berlin : Weidmann, 1903. $601 \mathrm{p}$.

9. Aristotle. Physics. Oxford : Oxford University Press, 2014. $384 \mathrm{p}$.

10. Galey A. Reading McLuhan reading Ulysses. Canadian Journal of Communication. Vol. 44. № 4. 2019. P. 503-526.

11. Young L.C. The McLuhan-Innis field: In search of media theory. Canadian Journal of Communication. Vol. 44. № 4. 2019. P. 527-544.

12. Харарі Ю. Людина розумна. Історія людства від минулого до майбутнього. Харків : Клуб Сімейного Дозвілля, 2016. 544 с.

13. Tranberg P. From humanism to dataism. A future scenario. DataEthics. URL: https://dataethics. eu/humanism-dataism-future-scenario/ (date of access: 26/01/2021).

14. Piacentini M., Limmer M., Hennell K. Ethical dilemmas using social media in qualitative social research: A case study of online participant observation. Sociological Research Online. Vol. 25. № 3. 2019. P. 473-489.

15. Bahuguna A., Bisht R.K., Pande J. Country-level cybersecurity posture assessment: Study and analysis of practices. Information Security Journal. Vol. 29. № 5. 2020. P. 250-266.

\section{Анотація}

Олейник А. О. Нова людина в ері технологій. Стаття.

Сучасна філософія, займаючись вирішенням аналізованих нами проблем, не може дійти консенсусу. Метою дослідження є виявлення проблематики інформаційних технологій на основі праць Маршалла Маклуена. Завдання - провести емпіричний експеримент для виявлення 
перспективи розвитку людини та дослідження поняття «глобальне село», його актуальності у сучасному житті та майбутньому. Стаття розглядає проблематику інформаційно-технічної революції, ïi розвиток і вплив на сучасну людину. Проведене дослідження висвітлює проблеми, з якими зіштовхується людина протягом життя, новітні філософські поняття, що відображають потенційне майбутнє людини сьогодення та світу навколо неї. Автор наводить власні думки із приводу розвитку інформаційних технологій, вводить новий термін і розглядає людину як частину інформаційно-технологічного світу. Методи розв'язання цього питання включають у себе введення нових законів у існуючих сферах життя людини та тих, що з'явилися із приходом інформаційних технологій. Використання цих методів розширює обсяг філософських вчень і їхню направленість, дає змогу узгодити розвиток технології паралельно 3 новими введеними законами у сферах сучасного людського життя. 3' ясовано, що філософська проблема інформаційних технологій залишається відкритою. У майбутньому актуальність цієї проблеми ростиме, оскільки давно триває перелаштування життя суспільства в онлайн-простір, що відбувається завдяки технологіям. Вирішенням поставленої проблеми може стати обмеження впровадження технологій у життя людей. Отже, інформатизація має регулюватися, тобто людству необхідно контролювати її вплив на розвиток, світогляд і відчуття цивілізації. Це допоможе зберегти homo sapiens як у філософському контексті існування, так і у фізичному сприйнятті у сьогоденні та майбутньому.

Ключові слова: глобальне село, датаїзм, техногуманізм, мас-медіа, інформатизація.

\section{Summary}

Oleinyk A. O. A new man in the era of technology.Article.

Modern philosophy, dealing with these problems, cannot come to a consensus and common opinion. The purpose of this study is to identify the problems of information technology based on the works and scientific works of Marshall McLuhan. The task is to conduct an empirical experiment to identify the prospects for human development and study the concept of "global village", its relevance in modern life and the future. The article considers the problems of information and technological revolution, its development and impact on modern man. The study highlights the problems faced by a person throughout life, as well as their prospects for future development. The author of the article highlights the latest philosophical concepts that reflect the potential future of man today and the world around him. The author gives his own thoughts on the development of information technology, introduces a new term and considers man as part of the information technology world. Methods to address this issue include the introduction of new laws in existing areas of human life and those that have emerged with the advent of information technology. The use of these methods expands the scope of philosophical teachings and their focus, allows to coordinate the development of technology in parallel with the newly introduced laws in the fields and spheres of modern human life. It has been found that the philosophical problem of information technology remains open. In the future, the urgency of this problem will grow, as it has long been the reorganization of society into an online space, which is due to technology. The solution to this problem may be to limit the implementation of technology in the lives of people without formed Thus, informatization must be regulated, i.e. humanity needs to control its impact on development, worldview and sense of civilization.

Key words: global village, datism, technohumanism, mass media, informatization. 